\title{
National and transnational structuring of the British
}

\section{corporate elite}

\section{Bruce Cronin}

\section{1) Introduction}

Corporate power in Britain is multifaceted, multilayered, and geographically structured. In contrast to the classic rise of the capitalist class, the established landed aristocracy was not overthrown in Britain but became embedded in its ascendancy, an articulation strongly marking institutional forms of power to this day (Anderson 1964). The industrial revolution that drove the accumulation of national wealth in $19^{\text {th }}$ century Britain had had its catalyst in the wealth of international trade and plunder, and in turn was quickly followed by international corporate expansion. British capital dominated international investment through to the Second World War and today still accounts for the world's second largest of overseas direct investment stock (Dunning and Archer 1987, United Nations Conference on Trade and Development 2011). So the British corporate elite are intimately structured by a complex of national and transnational influences. 
Periodic attempts to delve into the growing documentary archive of elite relationships in Britain have barely pierced the outer layers of the structures of corporate elite cohesion, however. The availability of data and the potentially strategic importance of a director's role has led attention primarily towards interlocking directorships (Aaronovitch 1956, Useem 1984, Windolf 2002), while the mining of biographical databases provides an entry-point into elite schools, clubs and social circles (Sampson 1962). But these are only limited components of the taxonomy of multiple layers of inter-organisational bonds proposed by Scott and Griff (1984) as constituting elite cohesion, let alone extended to national and transnational dimensions (see Table 1).

[Table 1 about here]

This paper takes a modest taxonomic step through these layers, reviewing and extending Scott's periodic studies of British director interlocks, temporarily and methodologically, then considering the pattern of interlocks in the context of transnational influences on the British economy.

\section{2) Studies of the British corporate elite}

There is a rich vein of historical analysis of the development of British capitalism, sifting archives to meticulously document the rise of a wide variety of industries and the large firms that have come to dominate them. While much of this research initially considered the relatively slow growth of British corporate capitalism after pioneering industrialisation, as compared to the US and Germany, a re-examination from the 1970s highlighted the early and persistent internationalisation of British industrial firms.

British merchant houses, originally establishing offshore agencies to facilitate international trade, diversified from the early $19^{\text {th }}$ century into episodic banking, 
construction, plantations and manufacturing; Jardine Matheson and $\mathrm{P} \& \mathrm{O}$ originate from this time. Specialist companies followed the merchants offshore to finance and insure trade. Barings and Pheonix Insurance established US branches in the early 1800s While the pioneers of industrial expansion abroad were US, British firms followed from the 1860s with textile and steel manufacturers establishing subsidiaries in the rapidly growing, but protected, US market; by 1914, 14 of the 100 largest British manufacturing firms had overseas operations (Stopford and Turner 1985). In all, British overseas assets increased rapidly in the second half of the $19^{\text {th }}$ century, from $£ 1.1$ billion in 1850 to $£ 5$ billion in 1874 and $£ 11$ billion in 1900,45 per cent of the latter comprising direct investments. Total overseas assets equalled one third of national wealth and accounted for half of the world's investment stock. British capital dominated international investment through to the Second World War, accounting for 40 per cent of the total in 1939 and today still accounts for the world's second largest of overseas direct investment stock (Barratt Brown 1974, Corley 1994, Dunning and Archer 1987, Edelstein 2003, Jones 1988, Nicholas 1983, United Nations Conference on Trade and Development 2011).

While the historical research on large firms has been largely descriptive, at times it has resonated with the delineation of articulated structures of power, most notably synthesised around the concept of 'gentlemanly capitalism'(Cain and Hopkins 2001). This highlights the clubbish interconnections among the landed aristocracy and the City of London as critical to the funding of rapid capitalist expansion, both as a source of strength and myopic weakness. Ingram (1984), for example, attributes British post-war industrial decline to the disproportionate political power of the City, echoed in recent commentary on the 2008 financial crisis. 
Attempts to delineate the corporate elite more systematically have predominantly centred on the social relationships formed when a member of a board of directors of simultaneously serves on the board of directors of another company. These multiple directorships constitute social relations between the boards, described as interlocks, and provide a potential conduit for the transfer of strategically valuable information among a group of linked firms. From a resource-based view of business behaviour, such connections are especially valuable for firms facing uncertainty, providing opportunities to reduce uncertainty with specific knowledge about competitors' plans, debtors' intentions, or greater knowledge of the business environment in general.

The suggestion that interlocks provide strategically important information channels is supported by the nationally distinctive patterns of director interlocking, with the UK and US characterised by low rates of interlocking (Carroll and Fennema 2002, Stokman, et al. 1985, Windolf 2002). However, while this may appear to relate to the more marketoriented capital funding in these countries (Scott 1991), there is little explicit relationship between funding requirements and interlocking other than as a response to financial difficulties (Mizruchi and Stearns 1988). The trend may simply reflect differences in the number of large, domestic or financial firms, and those with large minority shareholders, each of which is associated with interlocking (Carroll and Alexander 1999, Dooley 1969, Ornstein 1984). At the same time, while there has been little evidence of collusive behaviour arising from these communication channels, interlocks have been associated with the diffusion of business practices, including quality management, takeover defences and political donations (Bond 2004, Mizruchi 1996). 
Possibly most significantly, interlocks appear to provide a general 'scan' of the business environment, important to strategic decision-making (Useem 1984). Generalising the resource-based approach, firms may use this scanning capacity to reduce uncertainty in industries or markets where information is less transparent. Financial institutions might be expected to have larger boards and thus greater scanning capacity because of the opacity of the affairs of borrowers. Likewise, foreign-owned firms operating in a less familiar business environment and firms dependent on government concessions.

Scott and Griff (1984) note how director interlocks represented only one of a multiple set of bonds that structured corporate elite cohesion, each providing a channel for exchanges and flows of money, materials and information (see Figure 1). Scott (1986) commences the more extensive investigation demanded by this taxonomy by supplementing director interlock studies with a consideration of ownership type, introducing the useful concept of ownership by a 'constellation of interests' (Nyman and Silberston 1978). Such shareholdings tend to be held by institutional investors, insurance companies and fund managers displacing family ownership between 1936 and 1951. However, in 1976, $21 \%$ of firms remained controlled by an entrepreneurial interest, and $20 \%$ by a family, while $14 \%$ of firms had family involvement in a constellation of interests.

Later, Scott (1991) broadly scopes the articulation of the various levels of elite cohesion with an account of membership of social groups (see also Francis 1980, LisleWilliams 1984). Somewhat more systematically, albeit with a limited sample, Brayshay, Cleary and Selwood (2007) examine the geographical location, school origins and club membership of directors of 12 prominent highly internationalised UK trading and banking firms in 1900 and 1930. They find the geographic distribution of directors 
related to the geographic pattern of each firm's commercial activity and the persistence of both this geographic distribution and corporate connections with particular social clubs over the 30 year period.

A systematic examination of the British corporate elite, then, requires analysis of a set of inter-organisational relationships, embracing commercial, capital and personal relations. Data availability steers investigation towards director interlocks and shareholding relationships in the first instance, as pioneered in the UK case by Scott. But given the relatively well-documented international interaction of UK firms, it seems a feasible extension of Scott's work to consider the transnational influences on these drivers of elite cohesion.

\section{3) Methods and data}

A comparative cross-sectional approach is used to examine the evolution of the structure of British director interlocks over the last century. Scott's studies of the interlock structure in 1904, 1938 and 1976 (largely reported in Scott and Griff 1984) are supplemented by original studies of the interlock structure in 2006 and 2009, before and after the 2007-8 financial crisis. Consistent sampling and methodologies were employed, as much as could be ascertained from the published accounts. Metrics on the structure of the interlock network provided by Scott were sufficient for systematic comparison at all five time-points.

For the supplementary 2006 and 2009 cross-sections, data on directors were drawn from the Bureau van Dyke Orbis database for the 250 largest UK firms by revenue. Because this listing included holding as well as operational companies, this was reviewed, 
excluding direct subsidiaries and operational companies where directors and revenues were substantially the same as the holding company, a method implicit in Scott's work. ${ }^{\mathrm{i}}$ Also excluded were limited liability partnerships, the large accounting firms whose many partners were formally recorded as directors.

For comparison with Scott's earlier findings, descriptive statistics were drawn for each cross-section, using UCINET 6.0 (Borgatti, et al. 2002), including a component analysis and a listing of the ten most central firms each year, in terms of degree centrality. Alternative measures of centrality, such as betweenness, closeness and eigenvector centrality were found by Scott and Griff (1984) to be highly correlated.

Following the comparison of network metrics across the five-cross sections, a listing of the ten most central firms for each period provides the basis for an historical consideration of the evolution of the director network. Scott's approach, which reviewed the industrial basis of the most central firms against an account of the economic structure at the time, is extended to consider transnational influences at each period.

In Scott's work, the relationships formed between firms by sharing a common director is considered to be a network comprising the firms alone, a 1-mode firm-to-firm network among a standard number of firms (250). However, as the relationships between firms are actually constituted by firm-director-firm linkages, the network is actually more complex, larger, and the network size varies with the number of directors involved. This complexity and richness in the network structure is lost when the network is represented solely in 1-mode terms. 
As discussed by Borgatti and Everett (1997), it is important to account for the twomode nature of this data when normalising for network size. In Figure 1, the normalised degree centrality of $\mathrm{A}$ in 1-mode terms, the proportion of the maximum possible degree, is $2 /(4-1)=0.67$. But in 2 -mode terms, the maximum possible degree is given by the total nodes in the other mode, so the normalised degree of $\mathrm{A}$ is $2 / 4=0.50$. Similar arguments are given by Borgatti and Everett (1997) for betweenness, closeness and eigenvector centrality. Likewise, network density needs to account for the 2-mode nature of the data. One-mode directed data has a maximum of n(n-1) ties and undirected ties half of this, whereas in 2-mode data again the maximum ties is given by the total nodes in each other mode, n1.n2 for directed data and 2(n1.n2) for directed data. As a result of these considerations, a further centrality analysis was undertaken of the 2006 and 2009 data, listing the ten largest firms in terms of 2-mode degree, betweenness and closeness centrality.

[Figure 1 about here]

Finally, a more detailed examination of the effects of transnational influences on the director interlock structure in 2006 and 2010 was undertaken by means of a regression analysis. The dependent variable in each case was the degree centrality and closeness centrality of each firm; a visual inspection of the network suggested betweenness was subsumed by the latter. These were compared to a variety of indicators of financial performance, industry and transnationality. Financial indicators, found significant in other interlock studies, comprised Log Revenue, Return on Shareholders' Funds, Return on Capital Employed, Price Earnings Ratio and Solvency (Cronin and Popov 2005, Dooley 1969, Fligstein and Brantley 1992, Mizruchi and Stearns 1988, Ong, et al. 2003). The industry indicator used was the one-digit NACE code (as an ordinal range). 
Indicators of transnational integration comprised the percentage of UK sales, the percentage of directors resident outside the UK and whether the firm was foreign owned or not. These were derived predominantly from the Orbis geographic segment sales category, supplemented by company reports. In some cases for the UK sales percentage, the UK was not separately identified as a geographic segment, in which case the smallest next aggregation, typically Europe, was used.

The interdependent nature of network data renders it unsuitable for OLS regression as the interdependencies violate the assumptions of independence of variables and their normal distribution central to the OLS method, typically strongly overstating the statistical significance of correlations. Fortunately, the Multiple Regression Quadratic Assignment Procedure (MRQAP) regression technique, a modified OLS approach available in UCINET 6.0, provides a means of regressing interdependent data In lieu of a normal distribution, this uses a comparison with a large number of random permutations in the values associated with each node to test the significance of the observed values (Dekker, et al. 2007).

For the MRQAP procedure, a matrix was created for each variable, by taking the similarity or difference in the metric for each pair of nodes. These matrices were then compared to each other and to the differences in the dependent variable. The following model was used:

(1) $\Delta$ Centrality $=\alpha+\beta 1 \Delta \log ($ Revenue $)+\beta 2 \Delta$ ROSF $+\beta 3 \Delta$ ROCE $+\beta 4 \Delta$ PER $+\beta 5 \Delta$ Solvency $+\beta 6 \Delta \mathrm{NACE}+\beta 7 \Delta \mathrm{UK}$ Sales percent $+\beta 8 \Delta$ Foreign Director percent $+\beta 8 \Delta$ Foreign-owned $+\mu$ 


\section{4) Findings}

Network statistics of the director interlocks among the largest UK firms at the five timepoints are presented in Table 2 . There is remarkable stability in the number of directors and directors per board, and interlocks per interlocked firm across the century. But the number of directors serving on multiple boards, interlocked firms, firms in the largest component, number of strong components and thus the density of the network is considerably reduced. Within these general trends, the density of interlocks firms, indicated by multiple directors, total interlocks, firms interlocked, interlocks per interlocked firm, density, number of firms in the largest component and number of firms in the largest strong component increased in the first half of the twentieth century then declined thereafter. Between 1938 and 1976 there was an increase in the number of directors and consequently directors per board, but these were not as densely interlocked with the rest of the top 250 or its core. Interlocking declined further after 1976 on all counts except interlocks per interlocked firm, suggesting a consolidation of interlocks around a core. The 2008 global financial crisis appears to have had little effect on board size or overall density but there was a noticeable increase in multiple, and thus total, interlocks, firms interlocked and firms in the largest component. At the same time, the core of the network weakened, with an increase in the number of components but a decrease in the number of firms in the largest strong component. ${ }^{\mathrm{ii}}$

[Table 2 about here] 
Scott found the largest strong component in 1904 comprising 17 major familyconnected merchant and clearing banks in the City with no strong links with industry. The 13 London clearing banks had some interlocks with no more than 9 industrial firms. By 1938, the largest strong component had grown to 63 firms, still centred on the City family-based merchant banks but with connections into regionally-based heavy industry, which he described as "the characteristic pattern of British finance capital" (Scott 2003, 165). By 1976, the regional structure had been diffused by widespread small-shareholdings throughout the national economy by large financial institutions such as insurance firms and pension funds and the City firms were divided among different components. But the banks remained central to the interlocking director network. Following the financial deregulation of 1986 and increased foreign ownership, the interlock structure dissipated, with lower density, fewer bank interlocks and fewer financial-industry links by 1992.

While comparative data is not available for the first three periods, international dimensions of the network are evident from an analysis of the nationality of directors (see Table 3). A third of directors of the top 250 UK-registered firms in both 2006 and 2010 were resident outside the UK. These were drawn predominantly from Europe and North America, although perhaps surprisingly few from Asia, given the rapid economic growth of that region. Further disaggregation of the North American total combined with Australasia points to the continuing salience of the former British dominions in the UK's international business operations.

[Table 3 about here] 
Table 4 presents the ten most central firms in terms of degree centrality at each timepoint. The distribution suggests an industrial shift in the centre of the interlock network from railways in 1904 to banking and oil in 1938 to banking in 1976 and banking and consumer goods in 2006. Scott found the largest strong component in 1904 comprising 17 major family-connected merchant and clearing banks in the City with no strong links with industry. The 13 London clearing banks had some interlocks with no more than 9 industrial firms. By 1938, the largest strong component had grown to 63 firms, still centred on the City family-based merchant banks but with connections into regionallybased heavy industry, which he described as "the characteristic pattern of British finance capital" (Scott 2003, 165). By 1976, the regional structure had been diffused by widespread small-shareholdings throughout the national economy by large financial institutions such as insurance firms and pension funds and the City firms were divided among different components. But the banks remained central to the interlocking director network. Following the financial deregulation of 1986 and increased foreign ownership, the interlock structure dissipated, with lower density, fewer bank interlocks and fewer financial-industry links by 1992. Drawing on historical research it is possible to highlight transnational influences at each time-point, with firms maintaining operational subsidiaries overseas highlighted in bold. An internationalisation of the core of the network is evident, led by banking and oil, then generalised by the 2006-2010 period.

[Table 4 about here]

While the various measures of centrality are highly correlated in one-mode companycompany terms, when the relationships among the intermediary directors themselves are considered, that is two-mode company-director-company relations, the centrality metrics diverge. Degree centrality is weakly associated with closeness and betweenness 
centrality is negatively ( $r=0.42$ and 0.51 in 2006; $r=0.29$ and 0.39 in 2010) though the latter two are strongly correlated $(r=0.74 ; 0.76)$. The 2006 and 2010 columns of Table 3 illustrate the divergence of the two-mode centrality measures from one-mode degree centrality, with three firms central in one-mode terms not central in two-mode terms and only two firms being on the list by virtue of their two-mode degree centrality. Rather the one-mode degree centrality appears to be a weak and imprecise proxy for the correlation of two-mode betweenness and closeness.

Whereas the one-mode measure of degree centrality draws attention to banks and consumer goods firms, in the two-mode measure international banks and resources firms are more prominent (see Table 5). This is via their connections to a network of well-connected directors, which are reduced to single firm-to firm relationships when translated to one-mode data. There is also considerable disruption to the top-ten in twomode degree terms from the 2008 financial crisis, with only three survivors. Consumer goods firms are more prominent in the two-mode betweenness and closeness rankings, which also see a little more survival beyond the financial crisis. In general, the survivors tend to move from prominence in terms of degree centrality towards prominence in betweenness and closeness centrality, suggesting a consolidation of the core in the wake of the crisis.

[Table 5 about here]

Table 6 presents the results of the regression analysis of the 2006 and 2010 data. In both years, degree centrality was associated with revenue and the proportion of foreign directors, that is, larger firms and those with a higher proportion of foreign directors tended to have a larger number of interlocks. In 2010, degree centrality was also 
associated with industry, firms with higher NACE codes, that is towards finance, having more interlocks.

[Table 6 about here]

Closeness centrality was also associated with revenue in both years. However, in 2006, closeness was also negatively associated with UK sales, that is, firms with a greater proportion of overseas sales were more likely to be closer to all other firms in the director interlock network. In 2010, however, this was not evident and it was the more solvent and domestically-owned firms that had the greatest closeness centrality. There were no significant relationships with any other financial ratio tested.

\section{5) Discussion}

Scott's pioneering research relating the director interlock structure to the changing sectoral and geographic characteristics of the UK economy is supported by the evident internationalisation of the interlock network in the $21^{\text {st }}$ century. Large, domesticallyowned firms with transnational reach, largely in the banking and resource industries, dominate the centre of the interlock network. A significant minority of the directors of these firms are drawn from overseas but this is consistent with uncertainty avoidance by internationalising firms. Further, a number of domestically-oriented consumer goods firms remain central.

While Scott and Griff (1984) detected a concentration of the corporate elite to 1976, as mutual funds and banks displaced merchant family firms in ownership of the top 250 firms, the century-long trend is towards dissipation of power, with the 
internationalisation of the economy. While board size and interlocks per interlocked firm is surprisingly continuous, multiple interlocking and the large strong components have diminished. The increased multiple interlocking by larger financial firms and those with greater solvency following the global financial crisis, however, is consistent with the expectations of resource dependency theory, that firms seek to reduce uncertainty by increasing interlocking. This suggests a defensive reaction by a domestically-based fraction of the corporate elite, with disaggregation of the one-mode measures of centrality showing this group centrally close.

Consistent with Useem's notion of a corporate 'scan' and generalised resource dependency approaches, director interlocking has evolved as a strategic source of information where uncertainty is high. This generated a tight core where information circulated in merchant-families, a more extensive network as financial institutions became more central to ownership and national markets and financial risks became more generalised, then more diffuse as the corporate elite in general internationalised and overseas information became more important. That these are not invariable trends can be seen in the defensive interlocking associated with the immediate risks arising from the 2008 global financial crisis.

In sum, the pattern of director interlocking within the UK corporate elite over the last century reflects the transition of the economy from family-based merchant capitalism to regionally-based industrialism then international banking and resources. But this does not amount to a unilateral dissolution of the national economy into a global capitalism. Rather, the internationalisation of the largest firms remains strongly nationally based, domestically-owned, internationalisation of the directorate associated with external 
expansion and with a sizeable component comprising domestically-oriented consumer goods providers.

\section{6) Conclusion}

The multilayered nature of UK corporate power is evident in this examination of the changing articulation of director interlocking and transnational influences over the last century. British capitalism has been intrinsically structured by national and transnational processes from its start and the expansion of its nexus of activity from the national to global markets elides a complex articulation of corporate power that can be too readily interpreted as a diminution of national interests.

In the shadow of the United States, European Union, Japan and China, British capital remains the world's second largest overseas investor, with banking and resources firms at the heart of the global economy. Scrutiny of the structures of director interlocking over the century reveals a persistent national core among the UK corporate elite, not noticeably diminished by the shifts in the sectoral or geographical focus of economic activity.

The salience of Useem's corporate scan and generalised resource dependency models in explaining particular patterns of director interlocking is evident. While the search for oligarchic groupings amongst the corporate elite and direct firm-firm resource-exchange activities in various studies has been elusive, the value of the more generalised 
information seeking and uncertainty avoidance to the coherence of the corporate elite should not be underestimated.

Table 8.1. Inter-organisational bonds

\begin{tabular}{|l|l|l|}
\hline Relationship & National & Transnational \\
Shareholding & & \\
Bank credit & & \\
Commercial Relations & & \\
Joint-ventures and consortia & & \\
Parent-subsidiary & & \\
Business services & & \\
\hline Personal Relations & & \\
Director interlocks & & \\
Director friendships & & \\
Director kinship & & \\
\hline
\end{tabular}

Source: Adapted from Scott and Griff (1984) 
Table 8.2. Characteristics of director interlocks among 250 largest UK companies

\begin{tabular}{|l|r|r|r|r|r|}
\hline & 1904 & 1938 & 1976 & 2006 & 2010 \\
\hline Directors & 2204 & 2173 & 2682 & 2069 & 2061 \\
\hline Directors per board & 8.8 & 8.7 & 10.7 & 8.3 & 8.2 \\
\hline Multiple directors & 303 & 329 & 282 & 155 & 183 \\
\hline Total interlocks (incl. multiple) & 510 & 809 & 591 & 388 & 454 \\
\hline Interlocks between firms & 401 & 578 & 542 & 346 & 387 \\
\hline Firms interlocked & 197 & 201 & 189 & 119 & 145 \\
\hline Interlocks per interlocked firm & 2.6 & 4.0 & 3.1 & 3.3 & 3.1 \\
\hline Density (\%) & 1.3 & 1.9 & 1.7 & 0.6 & 0.7 \\
\hline Distinct components** & 9 & 4 & 3 & 1 & 4 \\
\hline Firms in the largest component & 177 & 194 & 185 & 105 & 113 \\
\hline Strong components* & & & & & \\
\hline Firms in the largest strong component & 17 & 63 & 13 & 6 & 3 \\
\hline
\end{tabular}

* Involving multiple ties between firms

** 3 nodes or more

Strong components with 3 or more members 2006: 
Table 8.3. Nationality of directors of UK 250 largest companies

2010

\begin{tabular}{lrr}
\hline Africa & 27 & $1 \%$ \\
Australasia & 35 & $2 \%$ \\
Asia & 57 & $3 \%$ \\
Europe & 266 & $13 \%$ \\
North America & 172 & $8 \%$ \\
UK & 1405 & $68 \%$ \\
Other & 28 & $1 \%$ \\
& & \\
No data & 71 & $4 \%$ \\
\hline Total & & \\
\hline
\end{tabular}

Note. There was no difference in distribution if measured in terms of unique directors or total directorships. 
Table 8.4. UK companies with the greatest degree centrality 1904-2010 (1-mode)

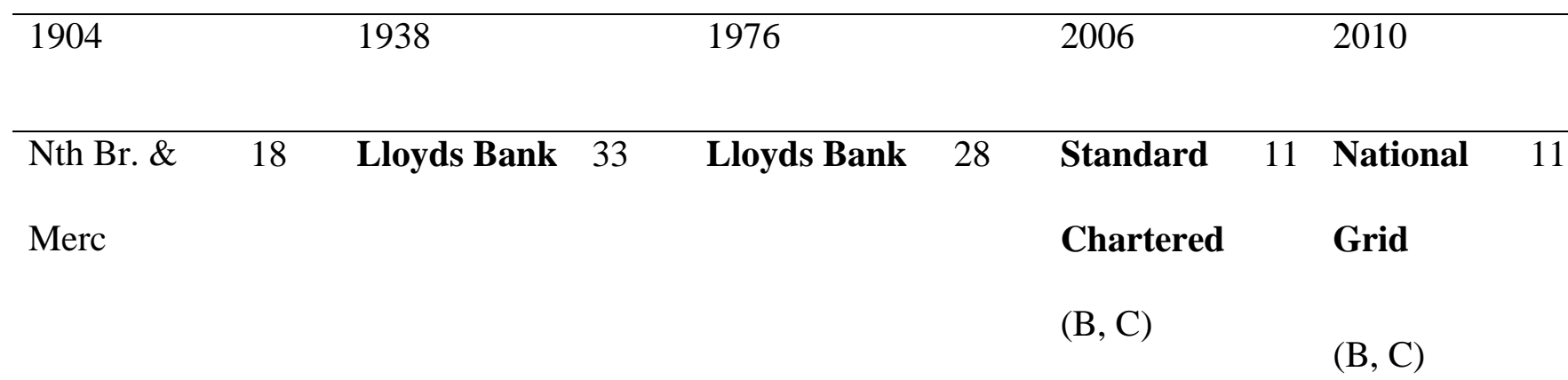

LNW

17 Midland

27 Bank of

26 Compass

10 Anglo

10

Railway

Bank

England

group

American

$(\mathrm{D}, \mathrm{B}, \mathrm{C})$

Royal

14 LMS

26 Midland

$21 \quad$ Lloyds

10 Reckitt

9

Exchange

Railway

Bank

TSB Bank

Benckiser

$(\mathrm{B}, \mathrm{C})$

$(\mathrm{B}, \mathrm{C})$

Bank of

13 Gt Western

24

BP

19

Unilever

9 Marks

England

Rly

$(\mathrm{B}, \mathrm{C})$

and

Spencer

$(\mathrm{B}, \mathrm{C})$

Nth Eastern $13 \quad$ Shell

21 Barclays

18

BP

8 Royal

7

Rly

Bank

$(\mathrm{D}, \mathrm{C})$

Bank of

Scotland 


\begin{tabular}{|c|c|c|c|c|c|c|c|c|}
\hline Dunderland & 12 & Bank of & 21 & Commercial & 18 & Rolls- & 8 & $\operatorname{Tesco}(\mathrm{C})$ \\
\hline Iron & & England & & Union & & Royce & & \\
\hline \multirow[t]{3}{*}{ GKN } & 11 & Sun & 19 & Nat & 18 & BUPA (C) & 7 & WM \\
\hline & & Insurance & & Westminster & & & & Morrison \\
\hline & & & & Bank & & & & \\
\hline Forth & 11 & LNE & 18 & Finance for & 17 & Wolseley & 7 & BT \\
\hline Bridge Rly & & Railway & & Industry & & & & \\
\hline Union of $\mathrm{L}$ & 11 & Westminster & 18 & Delta Metal & 16 & Barclays & 7 & HSBC \\
\hline \& S Bank & & Bank & & & & $(\mathrm{D}, \mathrm{B})$ & & $(\mathrm{D}, \mathrm{B}, \mathrm{C})$ \\
\hline GN \& & 11 & Venezuelan & 17 & Hill Samuel & 16 & Tomkins & 7 & Lloyds \\
\hline Piccadilly & & Oil & & & & (B) & & Banking \\
\hline
\end{tabular}

Source: Adapted from Scott and Griff (1984): 155

Note: 2006, 2010 - main component of 1-mode network

Bold - Has operational subsidiaries overseas

(D) In top-ten in terms of 2-mode degree centrality

(B) In top-ten in terms of 2-mode betweenness centrality

(C) In top-ten in terms of 2-mode closeness centrality 
Table 8.5. UK companies - Ranking by two-mode network centrality 2006-2010

\begin{tabular}{|c|c|c|c|c|c|c|}
\hline & $\begin{array}{c}\text { Degree } \\
2006\end{array}$ & $\begin{array}{c}\text { Between- } \\
\text { ness } \\
2006\end{array}$ & $\begin{array}{l}\text { Close- } \\
\text { ness } \\
2006\end{array}$ & $\begin{array}{c}\text { Degree } \\
2010\end{array}$ & $\begin{array}{c}\text { Between- } \\
\text { ness } \\
2010\end{array}$ & $\begin{array}{c}\text { Close- } \\
\text { ness } \\
2010\end{array}$ \\
\hline $\begin{array}{l}\text { Morgan Stanley } \\
\text { International }\end{array}$ & 1 & & & & & \\
\hline Camelot Group & 2 & & & & & \\
\hline HSBC Holdings & 3 & & & 3 & 8 & 9 \\
\hline Barclays & 4 & 5 & & & & \\
\hline $\mathbf{B P}$ & 5 & 7 & 4 & & & 7 \\
\hline British Sky Broadcasting & 6 & & & & & 10 \\
\hline Rio Tinto & 7 & & & 9 & & \\
\hline Unilever & 8 & 9 & 3 & & & \\
\hline Anglo American & 9 & & & 6 & 1 & 1 \\
\hline BAE Systems & 10 & & & & & \\
\hline Lloyds TSB Bank & & 1 & 1 & & 5 & \\
\hline Marks and Spencer & & 2 & 6 & & 3 & 4 \\
\hline Standard Chartered & & 3 & 2 & 7 & & \\
\hline
\end{tabular}




\begin{tabular}{|c|c|c|c|c|c|}
\hline Tomkins & 4 & & & & \\
\hline Cadbury Schweppes & 6 & 8 & & & \\
\hline National Grid & 8 & & & 2 & 3 \\
\hline Pearson & 10 & 5 & & 10 & 6 \\
\hline BUPA & & 7 & & & \\
\hline Tesco & & 9 & & 6 & 2 \\
\hline LogicaCMG & & 10 & & & \\
\hline Sabmiller & & & 1 & & \\
\hline Carnival & & & 2 & & \\
\hline United Company Rusal & & & 4 & & \\
\hline Tui Travel & & & 5 & & \\
\hline Prudential & & & 8 & & \\
\hline John Wood Group & & & 10 & & \\
\hline Reckitt Benckiser & & & & 4 & 8 \\
\hline IMI & & & & 7 & \\
\hline Smiths Group & & & & 9 & 5 \\
\hline
\end{tabular}

Bold - member of top-ten in both periods 
Table 8.6. Regression results - MRQAP

\begin{tabular}{|c|c|c|c|c|c|c|c|c|}
\hline \multirow{2}{*}{$\begin{array}{l}\begin{array}{l}\text { Standardised } \\
\text { Coefficients }\end{array} \\
\text { UK sales percent }\end{array}$} & \multicolumn{2}{|c|}{ Degree 2006} & \multicolumn{2}{|c|}{ Closeness 2006} & \multicolumn{2}{|c|}{ Degree 2010} & \multicolumn{2}{|c|}{ Closeness 2010} \\
\hline & 0.0120 & & -0.1651 & $*$ & -0.0003 & & -0.0803 & \\
\hline Foreign owned & -0.0000 & & 0.0000 & & 0.0000 & & -0.0000 & $*$ \\
\hline Directors foreign percent & 0.1455 & $*$ & -0.0034 & & 0.2674 & $*$ & -0.0267 & \\
\hline Log Revenue & 0.4331 & $* * *$ & 0.4034 & $* * *$ & 0.3112 & $* *$ & 0.4014 & $* * *$ \\
\hline NACE & -0.0210 & & 0.1137 & & 0.1288 & $*$ & 0.0332 & \\
\hline Price Earnings Ratio & -0.0397 & & -0.0573 & & -0.0783 & & -0.0264 & \\
\hline ROCE & 0.0560 & & -0.0120 & & 0.0254 & & 0.0768 & \\
\hline ROSF & -0.0163 & & 0.0394 & & -0.0261 & & -0.0160 & \\
\hline Solvency & -0.0120 & & -0.0222 & & 0.0380 & & 0.1437 & $*$ \\
\hline R-square & 0.261 & & 0.214 & & 0.229 & & 0.212 & \\
\hline Adj. R-square & 0.261 & & 0.213 & & 0.228 & & 0.212 & \\
\hline Probability & 0.000 & $* * *$ & 0.000 & $* * *$ & 0.000 & $* * *$ & 0.000 & $* * *$ \\
\hline Observations & 10920 & & 10920 & & 12656 & & 12656 & \\
\hline Permutations & 2000 & & 2000 & & 2000 & & 2000 & \\
\hline Missing values & 3948 & & 3948 & & 1526 & & 1526 & \\
\hline
\end{tabular}

$* \mathrm{p}<0.1 ; * * \mathrm{p}<0.01 ; * * * \mathrm{p}<0.001$ 
Figure 8.1. Data loss in transformation of 2 -mode to 1 -mode data
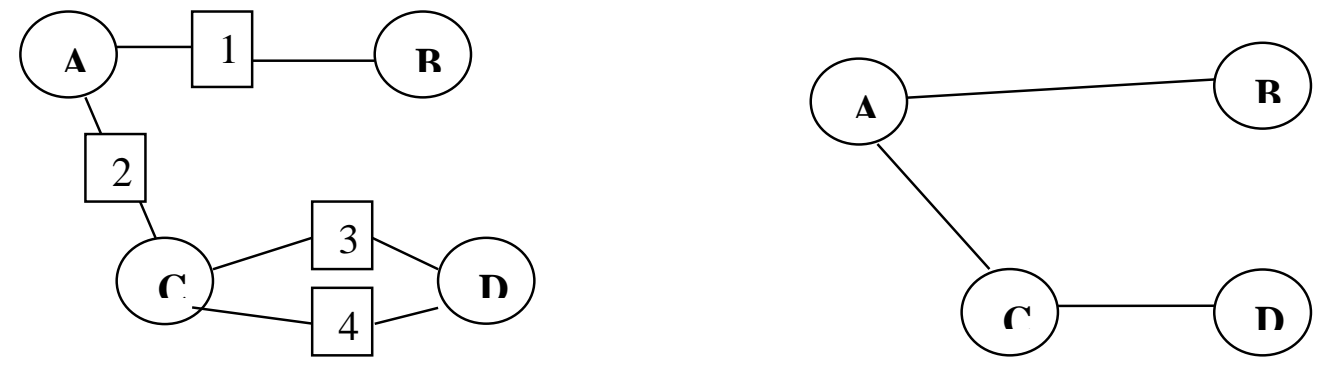

2- Mode

1-Mode 


\section{References}

Aaronovitch, S. (1956), The Ruling Class: A Study of British Finance Capital London: Lawrence and Wishart.

Anderson, Perry (1964), 'Origins of the Present Crisis', New Left Review (23), 26-53.

Bain, Harry Foster (1976), Ores and Industry in South America. New York: Arno Press. Barratt Brown, Michael (1974), The Economics of Imperialism. Harmondsworth: Penguin.

Bond, Matthew (2004), 'Social Influences on Corporate Political Donations in Britain', British Journal of Sociology, 55 (1), 55-77.

Borgatti, S.P., M.G. Everett, and L.C. Freeman, 'Ucinet for Windows: Software for Social Network Analysis' (Analytic Technologies, Harvard, MA, 2002).

Borgatti, Stephen P. and Martin G. Everett (1997), 'Network Analysis of 2-Mode Data', Social Networks, 19 (3), 243-269.

Brayshay, Mark, Mark Cleary, and John Selwood (2007), 'Social Networks and the Transnational Reach of the Corporate Class in the Early-Twentieth Century ', Journal of Historical Geography, 33 (1), 144-167.

Cain, Peter and Tony Hopkins (2001), British Imperialism 1688-2000. London: Longman.

Carroll, B. and M. Alexander (1999), 'Finance Capital and Capitalist Class Integration in the 1990s: Networks of Interlocking Directorships in the Canada and Australia', The Canadian Review of Sociology and Anthropology, 36 (3), 331350.

Carroll, William K and Meindert Fennema (2002), 'Is There a Transnational Business Community?' International Sociology, 17 (3), 393-323. 
Corley, T. A. B. (1994), 'Britain's Overseas Investments in 1914 Revisited', Business History, 36 (1), 71-88.

Cronin, Bruce and Vladimir Popov (2005), 'Director Networks and UK Corporate Performance', International Journal of Knowledge, Culture and Change Management, 4, 1195-1205.

Dekker, David, David Krackhardt, and Tom A. B. Snijders (2007), 'Sensitivity of Mrqap Tests to Collinearity and Autocorrelation Conditions ', Psychometrika, 72 (4), 563-581.

Dooley, P. C. (1969), 'The Interlocking Directorate', American Economic Review, 59 (3), 314-323.

Dunning, John H. and Howard Archer (1987), 'The Eclectic Paradigm and the Growth of UK Multinational Enterprise 1870-1983', Business and Economic History, 16 (1), 19-49.

Edelstein, Michael (2003), 'Foreign Investment, Accumulation and Empire', in Roderick Floud and Paul Johnson (eds), Cambridge Economic History of Modern Britain, Cambridge: Cambridge University Press, Vol. 2, pp. 190-226.

Fligstein, Neil and Peter Brantley (1992), 'Bank Control, Owner Control, or Organizational Dynamics: Who Controls the Large Modern Corporation?' American Journal of Sociology, 98 (2), 280-307.

Francis, Arthur (1980), 'Families, Firms and Finance Capital: The Development of Uk Industrial Firms with Particular Reference to Their Ownership and Control ', Sociology, 14 (1), 1-27.

Ingram, Geoffrey (1984), Capitalism Divided? The City and Industry in British Social Development. London: Macmillan. 
Jones, Geoffrey (1988), 'Foreign Multinationals and British Industry before 1945', Economic History Review, 41 (3), 429-453.

Lisle-Williams, Michael (1984), 'Merchant Banking Dynasties in the English Class Structure: Ownership, Solidarity and Kinship in the City of London, 1850-1960', British Journal of Sociology, 35 (3), 333-362.

Mizruchi, Mark S. (1996), 'What Do Interlocks Do? Analysis, Critique, and Assessment of Research on Interlocking Directorates', Annual Review of Sociology, 22, 271298.

Mizruchi, Mark S. and L. B. Stearns (1988), 'A Longitudinal Study of the Formation of Interlocking Directorates', Administrative Science Quarterly, 39 (1), 194-210.

Nicholas, Stephen (1983), 'Agency Contracts, Institutional Modes, and the Transition to Foreign Direct Investment by British Manufacturing Multinationals before 1939', The Journal of Economic History, 43 (3), 675-686.

Nyman, Steve and Aubrey Silberston (1978), 'The Ownership and Control of Industry', Oxford Economic Papers, 30 (1), 74-101.

Ong, Chin-Huat, David Wan, and Kee-Sing Ong (2003), 'An Exploratory Study on Interlocking Directorates in Listed Firms in Singapore', Corporate Governance: An International Review, 11 (4), 322-334.

Ornstein, Michael (1984), 'Interlocking Directorates in Canada: Intercorporate or Class Alliance?' Administrative Science Quarterly, 29 (2), 210-231.

Sampson, Anthony (1962), The Anatomy of Britain. London: Hodder \& Stoughton.

Scott, John (1991), 'Networks of Corporate Power: A Comparative Assessment.' Annual Review of Sociology, 17 (1), 181-202. 
Scott, John (1986), Capitalist Property and Financial Power: A Comparative Study of Britain, the United States and Japan. Brighton: Wheatsheaf Books.

Scott, John (1991), Who Rules Britain? Cambridge: Polity in association with Basil Blackwell.

Scott, John and Catherine Griff (1984), Directors of Industry: The British Corporate Network, 1904-76. Cambridge: Polity Press.

Stokman, F.N., R. Ziegler, and J. Scott (eds) (1985), Networks of Corporate Power: A Comparative Analysis of Ten Countries, Cambridge: Polity Press.

Stopford, John M. (1974), 'The Origins of British-Based Multinational Manufacturing Enterprises', The Business History Review, 48 (3), 303-335.

Stopford, John M. and Louis Turner (1985), Britain and the Multinationals. Chichester: John Wiley \& Sons.

United Nations Centre on Transnational Corporations (1988), Transnational Corporations in World Development: Trends and Prospects. New York: United Nations.

United Nations Conference on Trade and Development (2011), World Investment Report 2011: Non-Equity Modes of International Production and Development. New York and Geneva: United Nations.

United Nations Department of Economic and Social Affairs (1973), Multinational Corporations in World Development. New York: United Nations.

Useem, Michael (1984), The Inner Circle: Large Corporations and the Rise of Business Political Activity in the U.S. And U.K. New York: Oxford University Press.

Windolf, P. (2002), Corporate Networks in Europe and the United States. Oxford: Oxford University Press. 
${ }^{\mathrm{i}}$ This was not universally applied in the earlier studies, however. One of the 1938 ten most central companies, Venezuela Oil, was actually a subsidiary of Shell, another on the top-ten list (Bain and Read 1976).

ii There is little overlap between the one strong components in 2006 and the two in 2010, with only National Grid PLC being present in both. 